\title{
Adverse Rohingya Impacts on Bangladeshi aße Economy and its Solutions
}

\author{
Sudip Dey \\ Lecturer, Department of Economics, Premier University, Chattagram, BANGLADESH \\ *E-mail for correspondence: sudipdey1899@gmail.com
}

\begin{abstract}
Rohingya crisis is a crucial topic for recent time in world media. Due to injustice massacre on Rohingya, they took place in our country. This massacre was illegal and breaks the law of human rights. After arriving the Rohingya in Bangladesh, I have seen it had some adverse economic impacts on our Bangladeshi economy. From my study, I have seen it has effects on our tourism industry, unemployment, price hiking, banking sector, food security, and environment and so on. But the impact of Rohingya crisis on tourism industry was intolerable. At the end of my study, I have suggested some polices to solve the Rohingya crisis.
\end{abstract}

Keywords: Rohingya, Myanmar, persecution, economic impacts, solution, international organizations

\section{INTRODUCTION}

Rohingya are an ethnic group of Myanmar, and most of the people are Muslim. Rohingya Muslims practice a Sufi inflected variation of Sunni Islam. There are about 3.5 million in the world. In Myanmar there were 1 million Rohingya in Rhakine state, which was approximately one third of the total people. Myanmar's Buddhist group is differ from them for many causes. In fifteenth century they vestige their origin, when in Arakan Kingdom there were one thousands Muslims came for different purposes. But later Rhakine state was dominated by British and then rest of the Rohingya were arrived. There are approximately 1.1 million Rohingya people in the South Asian country. They have lived in Myanmar since as early as the $12^{\text {th }}$ century. They live in Rakhine state for many years, where they have co-existed uneasily alongside Buddhists for decades. According to their own view, they are descendants of Persian and Arab traders, who came Myanmar generations ago. Unlike the Buddhist in Myanmar they speak in Chittagonian language. All of Rohingya live in the western state of Rakhine of Myanmar and they are not allowed to leave without government permission. This area is the poorest and undeveloped are in Myanmar. Rohingya people lost their citizenship in 1982. It was known as Burma under British colonial rule (from 1824-1948) and there was significant migration between today's Myanmar, India and Bangladesh. Burma won independence in 1945 during the colonial period. After independence government of Burma passed the Union Citizenship Act but Rohingya were not considered as an ethnic group within 135 official ethnic groups and their ethnicity was included in the 1961 census. They fell in bad situation during the military coup in 1962 and in 1974, all citizens got national registration card but the Rohingya were not allowed to get national registration card, they were only eligible for foreign registration cards. They became stateless when a new citizenship law was passed in 1982. In 1998 the country was named Burma to Myanmar. Until recently, the Rohingya had been able to register as temporary residents with identification cards, known as white card, that the junta began issuing to many Muslims, both Rohingya and Non-Rohingya, in the 1990s. The white cards conferred limited rights but were not recognized as proof of citizenship. In 2009, a UN spokeswoman described the Rohingya as "Probably the most friendless people in the world" and it's easy to see why. An UNbacked national census was held in 2014, which was the first in 30 years. The Muslims were permitted to indentify as Rohingya, but for Buddhist nationalists it was abdicated. Then the government took decision that they could only register if they know as Bengali instead. Similarly, under pressure from Buddist nationals protesting the Rohingya's rights to vote in a 2015 constitutional referendum, the President Thein Sein cancelled the temporary identity cards in February 2015m effectively revoking their newly gained right to vote. 2015 's elections were widely touted by international 
monitors; there was no single candidate of the faith. "Country-wide anti-Muslim sentiment makes it politically difficult for the government to take steps seen as supportive of Muslim rights," writes the International Crisis Group. Muslim minorities continue to "consolidate under one Rohingya identity," says Lewa, despite documentation by rights groups and researchers of systematic disenfranchisement, violence, and instances of anti-Muslim campaigns. Boats packed with Rohingya migrants were left standed sea in 2015 then the commitment was become true. Many Rohingya were turned away from a number of Southeast Asian countries, including Malaysia, Indonesia, and Thailand. By referring to Rohingya as "Bengalis", the government is able to designate this persecuted minority as the "other". This perception of Rohingya as outsiders and illegal immigrants provides a not so subtle justification for the systematic disenfranchisement of the group and government's efforts to root them out of their homes. It implies they belong in Bangladesh, with other Bengali Muslims.

The main objectives of my paper are given below:

- To describe a historical background of Rohingya.

- To draw a scenario of the massacre of Myanmar military and Buddhists on Rohingya.

- To identify the adverse economic impacts of Rohingya crisis on Bangladesh.

- To develop a suggestion list to abolish this problem.

\section{ROHINGYA PERSECUTION}

Rohingya persecution started on 25 August 2017 when the Myanmar military forces and local Buddhist extremists began attacking the Rohingya people and committing atrocities against them in the country's north-west Rakhine state. During the persecution, there were thousands of Rohingya people were killed, according to United Nations reports about 690,000 refugees fled abroad (since 25 August 2017), destroyed many villages (354) and gang rapes and other forms of sexual violence against the Rohingya women and girls was the common scenario. When they had arrived in Bangladesh some women and girls were raped to death and others were found carrying raw wounds. Human Rights Watch reported of a 15 yearsold girl was raped by 10 Myanmar soldiers. The military and the local Buddhists killed at least 10,000 Rohingya people; they also displaced a large number of Rohingya people and made them refugees. Most of them were died by gunshot and others were burned to death in their homes. In December, two Reuter's journalists who had been covering the Inn Din massacre event were arrested and imprisoned. To save lives, the Rohingya people started fleeing Myanmar in large numbers and tried to take shelter in neighboring Bangladesh. The Myanmar military often opened fire with mortar shells and machine-guns on the fleeing Rohingya women and children, and dead bodies of many Rohingya people began to be washed ashore from the drowned boats as they attempted to cross the Naf River to enter Bangladesh. The Myanmar Army, Police Battalion and the Buddhist looted the houses of Rohingya and took away goats, cows, cattle and motorcycles. Thant Zin Oo, the commander of the $8^{\text {th }}$ Battalion, later sold the cows and the cattle in market.

\section{ECONOMIC IMPACT}

Bangladesh economy is facing multiple adverse impacts to give shelter the Rohingya refugees. Experts say if the recently arrived Rohingya from Myanmar's Rakhine state are not repatriated soon, the consequences would be the worst. The bad impacts are expected to include local food and price hike, food shortage, and reduction in tourism, along with raised pressure on our natural resources. At time foreign countries are supporting by giving foreign aid, but when it will stop, then these factors' intensity will be more visible. Experts said if we don't solve the crisis as early as possible a huge amount of money, food, cloths, house making instruments, health care services and natural resources will need to be allocated to support them. "Once our economy will be affected badly; food items and household materials will witness price hike. The government will have to revise the budget and increase the allocation. Otherwise, projects will be shelved and expenditures will be cut" (ABM Mirza Azizul Islam, 2017). He also said that Rohingya refugees spreading throughout the district would threaten tourism as tourists will be reluctant to visit over security issues and fears of possible chaos. In late August, according to the UN, about 480,000 Rohingya entered in Bangladesh and most of them took place in Ukhiya upazila, in Cox's bazaar. Local people said the prices of essential commodities were high. "The prices of almost everything have risen in the last two weeks due to higher demand following the Rohingya influx", (Shamsul Alam, a resident of Balukhalli 2017). For example, as of Monday in Ukhiya, Onions were selling at Tk60 per kilogram and potato at Tk40 per kg, compared to Tk45 and Tk25 respectively in Dhaka. Tourism expenditures in Cox's bazaar will be greatly reduced over the next 12 months certainly damaging the hotel and restaurant business. They may be some respite as there is likely to be a large inflow of foreign aid workers. For Bangladesh consumers, this will result from shifts in expenditures from tourism (in Cox's Bazaar) to other forms of consumption. Some of this shift may be to foreign travel but we can estimate that the effect will not be huge. Many Bangladesh households don't choose between going to Cox's Bazaar and going abroad. Tourism officials in Cox's Bazaar are serious about the upcoming seasons as the Rohingya don't left the camps. If the government does not solve the crisis as early as possible it will threaten and bad impacts on our hotel business, Cox's Bazaar hotel, requesting anonymity, told the Dhaka Tribune. He said the marine drive, one of the most attractive tourist spots on the coast, should be made inaccessible to all Rohingya. James Babu Hazra (2017), secretary-general of Bangladesh Hotel of Guest House Owners Association, told the Dhaka Tribune that holidaymakers should be reassured that the 
army is now monitoring the Rohingya issue. "The tourists won't face any security issues and will be able to move freely, but the businesses in Teknaf and Saint Martin's Island will suffer if proper measures are not taken", he said. The birthrate among the Rohingya is also much higher than that of Bangladesh; in 2018 alone, experts expect refugees to give birth to 48,000 babies-who will face severe risks of malnutrition, disease and death. Experts also informed about the housing and feeding cost of the 480,000 Rohingya, The current estimate stands at over $\mathrm{Tk6,400}$ core to $\mathrm{Tk} 8,000$ core a year for the refugees: up to $70 \%$ of Bangladesh's income per capita", (Ashikur Rahman, (2017)). Debapriya Bhattacharya (2017) said there were two types of costs involved in providing the stricken Rohingya with essential services: direct and indirect. The current situation has already cost us both directly and indirectly. Infrastructure, government services including security, natural resources, health and sanitation, and the labor market are included in indirect costs. "Direct costs include food and health services while indirect costs are incurred by the community an environment," he said. Bangladesh is facing unemployment problem, especially in Teknaf and Cox's Bazaar. The number of day labors is increasing due to Rohingya influx, and they agree to do work with lower wage. As a result, the native people are losing their job. Bangladesh's GDP per capita is a meager $\$ 1,400$. In 2016 the national economy grew by 7.1 percent, and the country has made remarkable progress toward the Millennium Development Goals. While extensive international humanitarian relief has poured in to support the refugees, that doesn't cover all the economic costs to the government or the border region's Bangladeshi citizens. The influx's full effect may not be apparent for some time. This crisis will lead to higher government and NGO expenditures. It will increase the level of the Government deficit and act as an expansionary force on the economy. Increased foreign aid flows and foreign NGO expenditure will, along with a higher deficit, lead to more rapid economic growth. On the balance the crisis will be an expansionary force on the economy. No impact on remittances or on exports should be expected. Some increase in foreign assistance expenditures will help the balance of payments but the effect will be limited. Its impacts can fall on export diversification, education system, power supply, foreign direct investment. Bangladesh increased its military expenditure to tackle this crisis. For handling the Rohingya camps many militaries were involved. During Rohingya influx we have seen some irregularities in credit management in banking sector, which is not good for economy. Huge amount of forest area was cleared Rohingya refugees, which worth is USD 18 million (Alam, 2017). It will cost ten million dollar to give shelter them, as a result its impact will be negative on our budget (Alam, 2017). Economic losses due to the refugee crisis will be countered to some extent by the influx of foreign aid workers. Foreign aid inflows and increased expenditures necessitated by the crisis could even have an expansionary effect on the Bangladesh economy with more rapid economic growth (Cookson, 2017). CPD said that Tk 1,356 crore were spent from March to August this year for Rohingya and Tk2,000 will be needed from September this year to February, 2018. Mentioning the report of the United Nations Human Right Commission, CPD said Tk 7,126 crore are urgently needed from September this year to June 2017 for Rohingyas. This amount is 1.8 percent of the Bangladesh national budget and 2.5 percent of total revenue, it said.

\section{SOLUTIONS}

- There were an estimated 300,000 unregistered Rohingyas in our country until October last year. Bangladeshi government can discuss with Myanmar government bilaterally and can sensitize different kinds of international organization so that they can take some pragmatic steps to solve the crisis. At this moment various organizations (UN, EU, OIC) are working for solving the problem, Bangladesh should provide all kinds of assistance. Suu Kyi needs to discuss this matter with her army generals. She and her country need to take responsibility on solving this problem peacefully.

- $\quad$ There are many touts beside the border who are doing business for transferring people from Myanmar to Bangladesh. So we should ensure good security and border cooperation, so that no illegal Rohingya can enter in our country.

- China offered a three-phase solution to mitigate the problem:

$>$ The first phase was to achieve a cease-fire. As a result, residents will not be displaced.

$>$ The second one was International community should instigate Myanmar and Bangladesh to discuss each other for a feasible solution to the issue.

$>$ The last one was the international community should support the Rakhine state for poverty alleviation.

- Bangladeshi Nobel prize owner Dr. Yunus proposes seven steps to solve Rohingya crisis:

$>$ Oversee the implementation of the ACRS recommendations.

$>$ Take steps to protect the violence and stop the outflow of Rohingya refugees.

$>$ Invite international observer's vulnerable areas on a regular basis.

$>$ Create conditions for the return of refugees who have already left the country.

$>$ Build camps within Myanmar for the returning refugees to facilitate their rehabilitation with UN financing and supervision.

$>$ Grant citizenship to the Rohingya as prescribed in the ACRS report under the exclusive authority of the implementation committee.

$>$ Guarantee and uphold political freedoms and the freedom of movement for all citizens. 
- Should build a security zone in Myanmar by UN and ensure safety for all people without concerning race and religion. It is necessary to send a team of the UNs Secretary-General to Myanmar for investigating the matter. Various organizations should create pressure on Myanmar government so that they don't do any kind offense and violence on Rohingya people.

- Many houses were burnt, people died, and resources were destroyed. Maynamar government should ensure they're compensate losses and need to give security to vulnerable populations. Besides these government need to conform their citizenship.

- Bangladesh and Myanmar recently announced an agreement for the repatriation of Rohingya refugees living in Bangladesh to return to Myanmar. Myanmar has agreed to resettle refugees in temporary camps. So Bangladesh government should take help from international organizations to implement the agreement.

- Have the UN, or some other neutral international bodies take a more active role in the situation. With many nations not willing to risk Myanmar, countries often turn their cheek to the Rohingya Crisis. This is why organizations like the HRC and UNHCR must take a more hands on approach administering humanitarian aid and safe routes to refugee camps and safe havens.

\section{CONCLUSION}

From the above study, it is easy to say that the adverse economic impacts of Rohingya crisis on Bangladesh were huge. I have discussed some suggestion, about how we can solve this problem. Since Rohingya are our neighboring country's people and Rhakine state is the poorest area in Myanmar, so we should give helping hand to them.
Different kinds of international organizations should think about them.

\section{REFERENCES}

"Act right now for permanent solution to Rohingya refugee crisis: Hasina to UN," (September 22, 2017), The Daily Star.

"Bangladesh faces economic crisis for Rohingya influx" (November 11, 2017), Daily Sun.

"Who are the Rohingya and what is happening in Myanmar?" (September 5, 2017), The Guardain.

Alam, M. (February 12, 2018), "How the Rohingya crisis is affecting Bangladesh and why it matters."

Aljeera (April 18, 2018), "Who are the Rohingya?"

Cooken, F. (April 20, 2018), "Impacts of the Rohingya crisis on Bangladesh (part-ii)," The independent.

https:/ / en.m.wikipedia.org/wiki/Rohingya_refugees_in _Bangladesh

https:/ / www.cfr.org/backgrounder/ / rohingya-crisis.

Husain, I \& Hossain, O. (September 28, 2017), "Rohingya influx may hurt Bangladesh economy," Dhaka Tribune.

Idris, I. (November 3, 2017), "Rohingya refugee crisis: impact on Bangladeshi politics (Helpdesk Report)".

Shibi, A. (October 30, 2017), "Bearing the economic cost of the Rohingya crisis," The Daily Star.

Taw, N.P. (November 20, 2017), “China proposes three-phase solution to Rohingya crisis, urges Myanmar, Bangladesh to solve issue bilaterally."

Wikipedia (2016), "Rohingya persecution in Myanmar,"

Wikipedia (2017), "Rohingya persecution in Myanmar,"

Yunus, D.M. (September 12, 2017), "Seven steps to solve Rohingya crisis," Dhaka Tribune.

Zaman, S.S. (September 7, 2017), "Bangladesh for peaceful solution to Rohingya crisis,"Dhaka Tribune.

$$
--0--
$$

How to Cite: Dey, S. (2018). Adverse Rohingya Impacts on Bangladeshi Economy and its Solutions. American Journal of Trade and Policy, 5(2), 81-84.

\section{SOCIAL SCIENCE RESEARCH NETWORK \\ 2171 Monroe Avenue, Suite 203, Rochester, NY 14618, USA \\ http://www.ssrn.com/en/}

SSRN Link: http://www.ssrn.com/link/American-Journal-Trade-Policy.html 